\title{
Anaerobic cellulolytic rumen fungal populations in goats fed with and without Leucaena leucocephala hybrid, as determined by real-time PCR
}

\begin{abstract}
The effect of Leucaena leucocephala hybrid-Bahru (LLB), which contains a high concentration of condensed tannins, on cellulolytic rumen fungal population in goats was investigated using real-time PCR. The fungal population in goats fed LLB was inhibited during the first 10 days of feeding, but after 15 days of feeding, there was a tremendous increase of fungal population $(157.0 \mathrm{gg} / \mathrm{ml})$, which was about fourfold more than that in control goats $(39.7 \varepsilon \mathrm{g} / \mathrm{ml})$. However, after this period, the fungal population decreased continuously, and at 30 days of feeding, the fungal population $(50.6 \varepsilon \mathrm{g} / \mathrm{ml})$ was not significantly different from that in control goats $(55.4 \mathrm{\varepsilon g} / \mathrm{ml})$.
\end{abstract}

Keyword: Condensed tannins; Leucaena; Real-time PCR; Rumen fungal population 